\title{
A PRIVÁT BANKI SZEKTOR NÖVEKEDÉSI TERE MAGYARORSZÁGON
}

Kazinczy Eszter

A pénzügyi intézményekben a privát banki tanácsadók és vezetők felelnek a leggazdagabb ügyfelek megtakarításainak kezeléséért. Magyarországon a privát banki tevékenység az 1990-es évek közepe óta minden releváns szempontból figyelemre méltó fejlődést mutatott. Ugyanakkor fennáll a lehetőség az ágazat további növekedésére is. A tanulmány becslést ad a piac lehetséges méretére, valamint további információkat is szolgáltat a szektor föbb jellemzőiről. Ezek számos kérdést vetnek fel, amelyekre választ kell találni az elkövetkező években. A kutatás a pénzügyi vagyonra és egyenlőtlenségre vonatkozó tendenciákra és statisztikákra épül. A tanulmány a privát banki szektor növekedési potenciáljára világít rá, amely további bővülési lehetőséget kínál a szektor számára.

JEL-kódok: D63, G21, G24, N24

Kulcsszavak: privát banki szektor, magyar privát bankok, egyenlőtlenség

\section{BEVEZETÉS}

Hagyományos megfogalmazásban a privátbankár az a bankár, aki saját maga birtokolja és kezeli bankját. Néhány bank már a korai szakaszában a vagyonkezelésre összpontosította tevékenységét. Mindazonáltal, a hagyományos családi tulajdonban lévő „privátbankok” a huszadik századi zavargások közepette eltűntek, vagy államosították azokat. Ezek többségét nagy univerzális bankok vásárolták meg. Néhány „hagyományos” privátbank (mint például a Pictet) vagy privát befektetési bank (például a Morgan Stanley vagy a Goldman Sachs) átalakult. Érdekes, hogy csak az 1980-as években indult újra a privát banki tevékenység, de ezzel egy új koncepció is teret nyert. A privát banki tevékenység megkülönböztethető területté vált a jelenkori banki tevékenységeken belül, továbbá néhány bank kimondottan a felső osztály vagyonkezelésére szakosodott (Cassis-Cottrell, 2015). Jelen tanulmány szerint a privát banki tevékenység olyan pénzügyi szakértők munkáját foglalja magába, akik a nagy értékü pénzügyi megtakarítással rendelkezö ügyfélkör eszközeit kezelik.

1 Kazinczy Eszter a Széchenyi István Egyetem adjunktusa. E-mail: kazinczy.eszter@sze.hu. 
A privát bankok (PB) kulcsfontosságú ügyfélkörrel, nevezetesen a legnagyobb pénzügyi megtakarítással rendelkező számlatulajdonosokkal foglalkoznak. A tehetősebb osztály a tömeges lakossági ügyfelekhez viszonyítva általában magasabb bevételt hoz, ebből kifolyólag a lojalitásuk minden bank számára fontos. Így ezen ügyfelek extra szolgáltatási kört is élveznek az alacsonyabb pénzügyi vagyonnal rendelkező szegmensekhez képest. A privát banki szakértők folyamatos kihívásokkal néznek szembe a termékskálával, a szabályozási rendszerrel, az informatikai fejlesztéssel, a szolgáltatás jövedelmezőségével, valamint a tanácsadók naprakész ismeretével kapcsolatosan. A listát lehetne még tovább is bővíteni, azonban van egy lényeges kérdés, amelyre az összes privát bank keresi a választ; méghozzá az, hogy mekkora az a befektetői kör, amelyben „halászhatnak”. A kérdés maga az általános hosszú távú üzleti tervezés szempontjából döntő jelentőséggel bír, mivel számos pénzügyi intézmény vezetősége ennek függvényében határozza meg a PB-szakértők számára az éves ügyfélszám és a „nettó új pénz” akvirálási céljait. Az ügyfélkör nagyságának közvetlen hatása van a jövedelmezőségre és elősegítheti a hatékonyság fejlődését, mivel egy esetleges nagyobb ügyfélkör lehetőséget ad a hatékonyság növelésére. Ez készteti arra a PB-szakértőket, hogy éves szinten növeljék az ügyfélkörüket. ${ }^{2}$ Ebből kifolyólag az ügyfélkör potenciális mérete kulcskérdés a PB-vezetők számára, hiszen az üzleti tervezés alapjaként szolgál. Ugyanakkor a társadalom leggazdagabb szegmense szük csoportot képvisel, és részben láthatatlan a hatóságok számára, így a becslést nem lehet könnyen elvégezni. Az elmúlt években a magyar privát banki piac lassúbb növekedési ütemet tükrözött, különösen az ügyfélszámokat tekintve. A pénzügyi eszközök növekedését vizsgálva, a privát banki növekedési ráták számos esetben nem múlták felül a teljes háztartások növekedésére vonatkozó értékeket. Ezen tények alapján a releváns írások ${ }^{3}$ arra utaltak, hogy a PB-piac közel lefedett, azaz a privát banki üzletág már megszerezte a potenciális ügyfelek nagy részét.

A cikk elsődleges célja, hogy megcáfolja ezt a feltételezést, és közelítő becslést adjon a potenciális célcsoport méretére. A továbbiakban a potenciális ügyfélkör esetében két mutatót vizsgálunk: az egyik a lehetséges ügyfélszám, a másik a potenciálisan kezelhetö pénzügyi vagyon (asset under management), forintban denominálva. Az utóbbi mutatót a privát banki szférában használják, és az ügyfelek pénzügyi megtakarításait méri, azaz azt a vagyonmennyiséget, melyet a privát bankárok kezelnek. A mutató kiszámításához az aktuális piaci értékeket kell felhasználni. A pénzügyi vagyon természetesen nem foglalja magába a „fizi-

2 Utalhatunk a „méretgazdaságosságra” is, amely a mennyiség növelésével az egységre eső, csökkenő kibocsátási költségekre vonatkozik egy bizonyos határig.

3 Tekintse meg a Portfolio.hu privát banki szolgáltatásokról szóló, legfrissebb cikkeit. 
kai” megtakarítási eszközöket (például ingatlanokat vagy értékes festményeket). A számítás során figyelmen kívül hagyják a pénzügyi kötelezettségek oldalát is.

A tanulmány elején két tényezőt kell tisztázni az ügyfélszámok kérdéskörében. Először, hogy az egyéneknek több banknál is lehet PB-számlájuk. Ugyanakkor a becslés során az ügyfélszámot és az ügyfélszámlák számát azonosnak tekintjük. Másodszor, a becsléseink a háztartások statisztikáin alapulnak, nem pedig egyénekre vonatkoznak. Ennek eredményeként előfordulhat, hogy vannak olyan háztartások, ahol egynél több személy nyit PB-számlát. Az elemzés során ki fogunk térni ezen két torzító tényező lehetséges hatásaira.

A cikkben elsősorban ezen két kulcsfontosságú mutatót - nevezetesen az ügyfélszámot és a kezelt vagyont - elemezzük, de egyes szakaszokon belül a hangsúly egyikről a másikra tolódhat. Ez a két egymással összefüggő mutató mérőpálcának is tekinthető, és beletartozik a privát bankok legfontosabb teljesítménymutatói közé. Ennek eredményeként kiemelt részét képezik az éves üzleti terveknek és a közzétett statisztikáknak. Továbbá, az említett mutatók közvetlenül kapcsolódnak a privát bankok nyereségességéhez. Mindemellett olyan hatékonyságot mérő mutatók alapját is biztosítják, mint amilyen például az egy tanácsadóra jutó ügyfelek száma. Jelen cikk alkalmazott módszertana alapján szándékunkban áll bebizonyítani, hogy mindkét fö mutató tekintetében a PB-üzletágak növekedésére további lehetőségek állnak rendelkezésre. Így a cikk alapvető kérdésére - nevezetesen, hogy van-e még szabad tér a privát banki szektor növekedésére - határozott választ adhatunk. E tanulmány másodlagos célja, hogy rövid áttekintést nyújtson a magyar privát banki piac fejlődéséről és jelenlegi helyzetéről. Ez a jobb megértést szolgálja, egyben tisztázza az alkalmazott terminológiákat is.

A privát banki tevékenységről szóló tudományos irodalom meglehetősen korlátozott, Magyarország esetében pedig hiányos. Ennek ellenére rendelkezésre állnak statisztikai adatok és cikkek is. További tanulmányok folynak az egyenlőtlenségről is, ami szorosan kapcsolódik a privát banki tevékenységhez. Jelen tanulmány hozzá kíván járulni a pénzügyi szolgáltatások irodalmához, pontosabban a privát banki tevékenységről és annak növekedési potenciáljáról szóló irodalomhoz. Ez a munka elsősorban a magyar piacra fókuszál, és csak összehasonlítás céljából érint helyenként globális vagy európai uniós (EU-s) tendenciákat.

A tanulmány a következőképpen épül fel: a 2. fejezet áttekintést nyújt a magyar privát banki szektor főbb jellemzőiről, tükrözi a sokszínűséget, a piac méretét, a koncentrációját és a növekedés tendenciáit. Ez a fejezet a magyar privát banki szektor fejlődésének megértését szolgálja. Egy alfejezet a szektor legfontosabb kihívásait sorolja fel, amelyek a PB-piac méretével és hatékonyságával kapcsolhatók össze. A lista további elemzések lehetőségét is magában hordozza. A 3. fejezet az egyenlőtlenségek tendenciáit tartalmazza, valamint releváns információkat nyújt a magyar piac vagyoni helyzetéről. E témák a cikk megállapításait és elvárásait 
támasztják alá. A 4. fejezet három alfejezetet tartalmaz. Az első rávilágít annak fö okaira, hogy a PB-célcsoport miért nem mérhető pontosan. Szintén kitérünk az egyes módszertani megközelítések hiányosságaira. A következő alfejezet a cikk alkalmazott módszertanának áttekintésére szolgál. A 4.3. alfejezet az ismertetett módszertannal becsüli meg a lehetséges privát banki potenciál nagyságát. A cél megválaszolni, van-e további növekedési potenciál a $\mathrm{PB}$-üzletág számára. Az utolsó fejezetben levonjuk a következtetéseket, és összefoglaljuk a tanulmány főbb üzeneteit. A cikk egy függeléket is tartalmaz, amely reprezentálja egy releváns görbe illeszkedésének eredményeit.

\section{A MAGYAR PRIVÁT BANKI SZEKTOR JELLEMZÖI}

\subsection{A magyar privát banki szektor sokszínüsége}

Jelen alfejezet a 2018. évi statisztikák alapján nyújt információt a magyar privát banki piac helyzetéről. Az ezt követő alfejezet a PB-üzletág legfontosabb kihívásait részletezi. E kihívásokat azért fontos megemlíteni, mert mind a kezelt vagyonhoz és ügyfélszámhoz, mind pedig a hatékonyságot mérő mutatószámokhoz kapcsolódnak. Az 1. ábra a kiemelt alapmutatók alakulását tükrözi:

\section{1. ábra}

\section{A privát banki szektor föbb növekedési adatai}

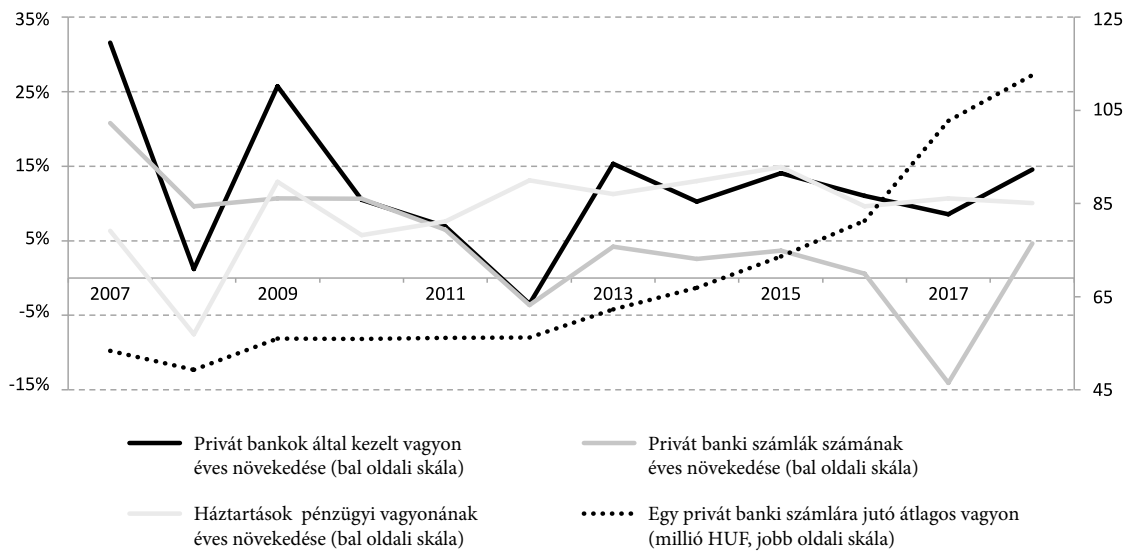

Megjegyzés: A hivatkozott statisztikák alapján számítottuk ki a növekedési ráták és az átlagos kezelt vagyon alakulását. Az utóbbi mutatószámnál a teljes PB-s kezelt vagyont osztottuk el a PB-s ügyfélszámlák számával.

Forrás: Portfolio.hu: Privát bankok, MNB-statisztikák, saját számítások 
Most a 2018-as statisztikai adatokhoz fordulunk. 2018-ban a magyar háztartások teljes pénzügyi vagyona 53583 milliárd forintot tett ki (MNB-statisztikák). Az 1 . táblázat megmutatja, hogy ennek a pénzügyi vagyonnak a $9 \%$-át a privát banki piac lefedte. Ez a százalék 2006-ban még csupán 6\%-ot ért el, és az évek folyamán fokozatosan növekedett (MNB-statisztikák; Portfolio.hu, 2007). Ez különösen figyelemreméltó abban az esetben, ha számításba vesszük a növekvő szegmentációs határokat. ${ }^{4}$ Ez magyarázza az 1. ábrán is látható PB-s számlák számának alkalmankénti csökkenését, valamint az átlagos kezelt vagyon növekedését.

\section{1. táblázat}

A magyar privát banki szektor föbb indikátorai (2018)

\begin{tabular}{|c|c|c|c|c|c|c|}
\hline $\begin{array}{l}\text { Privát bankok } \\
\text { listája }\end{array}$ & $\begin{array}{l}\text { Szegmen- } \\
\text { tációs } \\
\text { limit } \\
\text { (millió } \\
\text { HUF) }\end{array}$ & $\begin{array}{l}\text { Ügyfél- } \\
\text { számlák } \\
\text { száma }\end{array}$ & $\begin{array}{c}\text { Teljes } \\
\text { kezelt } \\
\text { vagyon } \\
\text { (milliárd } \\
\text { HUF) }\end{array}$ & $\begin{array}{c}\begin{array}{c}\text { Átlagos } \\
\text { kezelt } \\
\text { vagyon } \\
\text { (millió }\end{array} \\
\text { HUF) }\end{array}$ & $\begin{array}{c}\text { PB } \\
\text { tanácsadók } \\
\text { száma }\end{array}$ & $\begin{array}{l}\text { Egy tanács- } \\
\text { adóra jutó } \\
\text { uigyfél- } \\
\text { számlák } \\
\text { átlagos } \\
\text { száma }\end{array}$ \\
\hline Bank Gutmann & 320 & n.a. & 174 & n.a. & 5 & n.a. \\
\hline Budapest Bank & 25 & 3487 & 212 & 61 & 33 & 106 \\
\hline CIB & 60 & 3029 & 330 & 109 & 26 & 117 \\
\hline Concorde Securities & 75 & 800 & 151 & 189 & 9 & 89 \\
\hline Equilor & 25 & 347 & 28 & 81 & 2 & 174 \\
\hline Erste & 70 & 2915 & 475 & 163 & 24 & 121 \\
\hline Generali & 10 & 209 & 17 & 81 & 4 & 52 \\
\hline HOLD Alapkezelő & 80 & 648 & 165 & 255 & 8 & 81 \\
\hline $\mathrm{K} \& \mathrm{H}$ & 100 & 1243 & 178 & 143 & 18 & 69 \\
\hline MKB & 100 & 1750 & 545 & 311 & 26 & 67 \\
\hline $\begin{array}{l}\text { OTP (Private Banking / } \\
\text { Kiemelt Privát Bank) }\end{array}$ & $30 / 80$ & 22359 & 1699 & 76 & 166 & 135 \\
\hline Raiffeisen & 70 & 2446 & 529 & 216 & 41 & 60 \\
\hline SPB & 40 & 1509 & 61 & 40 & 14 & 108 \\
\hline Takarék & 20 & 870 & 48 & 55 & 9 & 97 \\
\hline UniCredit & 100 & 1550 & 245 & 158 & 13 & 119 \\
\hline Össz / Átlag & 75 & 43162 & 4857 & $108^{\star}$ & 398 & 108 \\
\hline
\end{tabular}

Megjegyzés: * Bank Gutmann kizárva.

Az összegek és átlagok saját számításokra épülnek.

Forrás: Portfolio.hu (2018), saját kalkulációk

4 A szegmentációs határ az a minimális pénzügyi vagyon, amelyet a privátbankok meghatároznak belépési korlátként. Például ha egy bank szegmentációs határa 50 millió forint, akkor olyan ügyfeleket akvirálnak, akik legalább ilyen összegben rendelkeznek pénzügyi megtakarításokkal. Meg kell jegyeznünk azonban, hogy egyes privátbankok limitjei - különösen az alacsonyabb szegmensek számára nyújtott szolgáltatások esetében - a havi jövedelmen vagy a teljes hitelállományon alapulnak. Nemzetközi szinten a szegmentálási üzletpolitikák szerteágazóak - lásd MAUDE (2006) vagy Euromoney (2018). 
A magyar privát banki piac több aspektusból nézve mindig változatos volt. A szegmentálást figyelembe véve, 2006-ban a belépési korlátok 10 millió forint és 400 ooo euró között szóródtak (Portfolio.hu, 2007), míg a limitek átlaga 42 millió forintot ért el. ${ }^{5} \mathrm{Az}$ idő múlásával a szegmentációs határok általában növekedtek, miközben a bankok megalkották az alacsonyabb vagyonnal rendelkező szegmens számára az úgynevezett „prémium” vagy „affluens” szolgáltatást. Mindkét tény eredményeként az alacsonyabb megtakarítással rendelkező ügyfélcsoportokat a privát banki szolgáltatástól egy alacsonyabb szegmens felé csatornázták át. 2018ban a szegmentálási tartomány már 10 millió és 320 millió forint között változott, míg az átlag 75 millió forintra növekedett (lásd 1. táblázat). Azonban ugyanebben az évben a privát banki számlák 39\%-a 50 millió forintnál alacsonyabb kezelt vagyonnal rendelkezett (Portfolio.hu, 2018). Ennek számos oka lehet. Elöször is ez a százalék a piaci átlagra vonatkozik, míg az egyes szolgáltatók az adott szegmentációs limiteket meghaladó átlagos vagyonnal rendelkeznek.7 Az is valószínüsíthető, hogy a meglévő PB-s ügyfelek jelentős része a szegmentációs limit alatti pénzügyi vagyonnal rendelkezik, ezen számlatulajdonosok azonban a jó kapcsolat vagy bizonyos presztízs következtében ilyen ügyfelek maradhatnak. Olyan esetek is léteznek, amikor a szolgáltatók azzal a feltételezéssel élnek, hogy egy adott ügyfél csupán átmenetileg nem rendelkezik az elvárt megtakarítással. Ezen kívül sok privát banki ügyfél a diverzifikáció céljából több bankban tartja a pénzét. Az említett tények alapján a privát bankokra vonatkozó statisztikákat nagyon óvatosan kell kezelni. Mindazonáltal még mindig észlelni lehet a piaci növekedést. Noha a számlák mennyisége az egyszeri hatások ${ }^{8}$ miatt akár csökkenhet, a kezelt vagyon

5 A súlyozott átlagot azért nem lehet kiszámítani, mivel a legnagyobb piaci szereplő - az OTP Bank - két privát banki üzletágat is működtet. Az elsőre 30 millió forintos szegmentációs határt használ, míg a második esetben 80 millió forint a belépési limit. Ugyanakkor az OTP Bank csupán a két terület összesített eredményeit teszi közzé. Amennyiben feltételezzük, hogy az OTP Bank mindkét területre az alsó korlátot használja, akkor a súlyozott átlag 67 millió forint lenne, míg a felső korláttal számolva, a súlyozott piaci átlag 86 millió forintra növekedne.

6 Általánosságban a „retail” és a PB-csoport között helyezkedik el az említett szegmens. Manapság az összes nagyobb magyarországi bank speciális szolgáltatásokat épített ki ezen ügyfélkör számára, amelyekkel befolyást gyakorolnak a privát banki csoportra. Pontosabban, a PB-szegmentációs határ sok esetben emelkedett, így azokat az ügyfeleket, akiknek a pénzügyi vagyona nem érte el az új limitet, átcsatornázták a köztes kategóriába.

7 Az SPB az új szegmentálási politikája miatt átmenetileg kivételt jelent.

8 Az egyszeri hatások általában új szegmentációs határokat, fúziókat vagy felvásárlásokat takarnak. Ugyanakkor olyan egyszeri lehetőségek is befolyásolni tudják az éves adatokat, mint például prémium államkötvények vásárlásának lehetősége lombardhitelekkel vagy adókedvezmények biztosítása „hazatérő” offshore megtakarítások számára. A vonatkozó egyszeri hatásokról olvasni lehet a Portfolio.hu privát bankokkal kapcsolatos cikkeiben. 
és a kezelt számlákon tartott átlagos vagyon növekszik, ami növekvő vagyonkoncentrációhoz vezet (lásd 1. ábra). ${ }^{9}$

A kínált termék- és szolgáltatásportfóliók szintén változatosak. Ezek kategorizálhatók az egyes szolgáltatók intézményi profilja, mérete és üzletpolitikája alapján. Általánosságban a kereskedelmi bankok a legszélesebb spektrumot fedik le. Kínált csomagjaikban a hagyományos banki termékek is megtalálhatóak - mint például folyószámlák vagy bankkártyák -, azonban eltérő költségszerkezettel vagy hozzáadott szolgáltatásokkal. Általánosságban elmondható, hogy a privát banki termékpalettán a befektetési eszközök és szolgáltatások dominálnak. A kínált befektetési termékek széles kört fednek le és változatosak, így beletartoznak épp úgy a különböző befektetési alapok, akárcsak a művészeti kincsek. A termékek különböző célokat szolgálhatnak; például adóoptimalizálást, devizadiverzifikációt vagy éppen nyugdíjazási terveket. Minden bank treasury osztálya vagy alapkezelője saját befektetési termékeket is kínál. Ezenfelül a privát bankok általában más nemzetközi vagy hazai alapkezelők befektetési termékeit is forgalmazzák. Számos privát bank úgynevezett „butik” stílusban forgalmazza a harmadik féltől származó befektetési termékeket, ahol az összes releváns termék elérhető az ügyfél számára, miközben mások inkább a „szemezgetést” részesítik előnyben. A szolgáltatásokat illetően az alapvető elem továbbra is a személyes befektetési tanácsadás. Ezt további szolgáltatásokkal lehet kiegészíteni, mint például öröklési tervezéssel vagy éppen jogi tanácsadással (Cassis-Cottrell, 2015; Portfolio.hu: Privát bankok).

Mindezeken kívül tisztázni kell, hogy mi a különbség a privát banki tevékenység és a privát vagyonkezelés között, mivel mindkét szolgáltatás a vagyonosabb ügyfelek pénzügyi vagyonkezelését foglalja magába. Az előbbi esetében a befektetési döntéseket az ügyfél és a PB-s tanácsadó közösen hozza meg. Az utóbbi esetben a befektetési szakértő menedzseli a megtakarítás bizonyos részét, az ügyfél céljait és kockázattűrő képességét figyelembe véve. Ezenkívül a privát banki szolgáltatás eltérő költségszerkezetet, valamint szélesebb szolgáltatási portfóliót takar. A rendelkezésre álló $\mathrm{PB}-\mathrm{s}$ statisztikák általában magukban foglalják az egyéni portfóliókezelést is, hiszen ezt a szolgáltatást jellemzően privát banki ügyfelek veszik igénybe (Portfolio.hu: Privát bankok).

A sokrétű tényezők listájának folytatása érdekében meg lehet említeni a díjstruktúrát is. Egyes szolgáltatók a kezelt pénzügyi vagyon százalékos értékét használják, néhányan díjat számítanak fel a tranzakciók után, míg mások inkább a fix havi díjat részesítik előnyben. A legtöbb esetben a PB-szolgáltatók ezen lehető-

9 A PB-piacon magas a koncentráció. 2018-ban az összvagyon 57\%-át a három legnagyobb piaci szereplő kezelte (Portfolio.hu, 2019; saját számítások). 
ségek kombinációit használják (Portfolio.hu: Privát bankok). Mindezek mellett a sokszínűség az egy tanácsadóra jutó ügyfélszámlák átlagos számának áttekintésekor is fellelhető. Ezen átlagok nem korrelálnak sem a számlákon meglévő átlag kezelt vagyonnal, sem pedig a szegmentálási korlátokkal (l. 1. táblázat).

Összegzésképpen elmondható, hogy a magyar PB-piac számos szemszögből igen sokszínünek tekinthetö. A kezelt pénzügyi vagyon szempontjából tovább növekszik a piac, miközben a számlákon is nő a vagyonkoncentráció. A számlák számát figyelembe véve, ez a koncentráció az emelkedő szegmentációs határok és a nagyobb kezelt pénzügyi vagyon eredménye. További változatosságot lehet észlelni a szegmentációs korlátok, a termékportfóliók, az alkalmazott díjstruktúrák vagy a tanácsadók által kezelt számlák számának ellenőrzésekor. Mindezen témakörök rávilágítanak a kezelt vagyon és számlák számának fontosságára, ami vizsgálatunk fö tárgya.

\subsection{A privát banki szektor kihívásai}

Ami a jövőt illeti, a privát bankoknak mind belföldi, mind pedig nemzetközi szinten számos kihívással kell szembenézniük. Ezek a próbatételek az ügyfélkört, valamint a bankvezetőket egyaránt érintik.

Nyilvánvaló, hogy a digitalizáció és a robotizáció egyre nagyobb szerepet kap a pénzügyi piacon is. A fiatalabb generáció kevesebb személyes találkozót igényel privát bankárával, viszont fontos számukra a korszerü elektronikus csatornák vagy akár a „robottanácsadók” használata. A blockchain-technológia szintén releváns terület..$^{10}$ Egyik oldalról elmondható, hogy a megfelelés ezen kihívásoknak óriási pénzügyi befektetéseket igényel. Másik oldalról nézve: manapság, amikor a marzsok és a jövedelmezőségek csökkentek, az új technológiák javíthatják az üzleti hatékonyságot. Adott esetben például egy tanácsadó több ügyfelet tud kiszolgálni.

További kihívásként a MiFID 2 (Markets in Financial Instruments Directive) bevezetését lehet megemlíteni, amelynek az előírásai az Európai Gazdasági Térségben lévő pénzügyi intézményektől óriási erőfeszítéseket igényeltek. A szolgáltatási struktúra bizonyos átalakításra szorult, és az új körülményeket minden ügyféllel tisztázni kellett. Az előírások teljesítése jelentős költségekkel járt. Összességében elmondható, hogy a rendszeresen változó uniós vagy nemzeti szabályozások szinte folyamatos kiigazításokat igényelnek.

10 Amennyiben többet szeretne megtudni a témáról és a kapcsolódó kihívásokról, 1. FILIPPIWRIGHT (2018). A digitalizációval kapcsolatos releváns adatok megtekintéséhez lásd World Bank (2018). 
A díjaknak és költségeknek az ügyfelek számára átláthatóbbaknak kell lenniük. Többek között ennek hatására a privát banki menedzsment munkájában szükséges a szolgáltatás- és termékajánlatok „kiélezése” és a megkülönböztető jegyek erösítése (McKinsey \& Company, 2016). Bizonyos pszichológiai szempontokat is figyelembe kell venni. A vagyonkezelők úgy reagálnak a legvagyonosabb szegmens módosuló hozzáállására és viselkedésére, hogy a befektetési termékekről és tranzaktálásokról a hangsúlyt egyre inkább a holisztikus befektetésre, valamint a cél alapú vagyonkezelésre helyezik ( $L i$-Huang, 2017).

A pénzügyi piacokon mindig fennáll egy bizonyos fokú bizonytalanság. Napjainkban számos befektetési szegmensben a kockázatok emelkedtek. ${ }^{11}$ Ezzel párhuzamosan - amint azt Janssen-Kramer (2015) is hangsúlyozza - még a potenciális ügyfeleknek is egyre több kérdésük van a várható kockázatokkal, hozamokkal és költségekkel kapcsolatban. A privát bankároknak meg kell felelniük az igényeknek, és válaszokkal kell szolgálniuk. Ki kell alakítaniuk olyan befektetési stratégiákat, melyekkel vonzó hozamokat tudnak biztosítani, miközben minimalizálják a piaci kockázatokat és teljesítik a MiFID 2 követelményeit.

Végül, de nem utolsósorban, a növekvő elvárások és a személyes kapcsolat szükségessége alapján a privát banki tanácsadóknak nagyon széles körü ismeretekkel kell rendelkezniük. Ugyanakkor, ezzel párhuzamosan, egyre nagyobb kihívást jelent a tanácsadók toborzása, képzése és tehetséggondozása (McKinsey \& Company, 2016). Mindezek eredményeképpen a privát bankok vezetősége érdekelt az egy tanácsadóra jutó ügyfélszámlák számának növelésében.

A fentiekben felsorolt témákkal összefüggésben ki kell hangsúlyozni, hogy ezek a kihívások relevánsak az egész bankszektor számára, pontosabban fogalmazva, a pénzügyi befektetéssel kapcsolatos szolgáltatások szempontjából. A privát banki szolgáltatások esetében ezen kihívások különös jelentőséggel bírnak a befektetési tanácsadási szolgáltatások jelentősége miatt. Mindazonáltal ezek a releváns témák a hatékonyság révén szorosan kapcsolódnak az ügyfélszámlák számához és a kezelt vagyon nagyságához, így a PB-piac növekedési terének felmérése kulcskérdés marad.

11 Példaként megtekinthető a VIX index alakulása, amelyet a pénzügyi piacokon „félelemindexnek" is neveznek. 


\section{RELEVÁNS ÜZENETEK \\ A MAGYAR PRIVÁT BANKI SZEKTOR SZÁMÁRA}

Ebben a fejezetben a társadalmi egyenlőtlenségről és a vagyonkoncentrációról nyújtunk olyan információkat, amelyek a privát banki potenciál becsléséhez relevánsak. Iránymutatást adnak mind a PB-ügyfelek számát, mind pedig a kezelt vagyon lehetséges nagyságát tekintve. Először, az egyenlőtlenségek ábrázolására egy egyszerü, de ugyanakkor széles körben használt mutatót használunk, nevezetesen a Gini-koefficienst. ${ }^{12}$ Bár vita folyik a használatáról, de célunkhoz jól használható egyszerű indikátorként. A 2. ábra Magyarország, az euróövezet és az Európai Unió adatait hasonlítja össze.

2. ábra

A rendelkezésre álló jövedelem Gini-koefficiense (EU-SILC felmérés, \%)

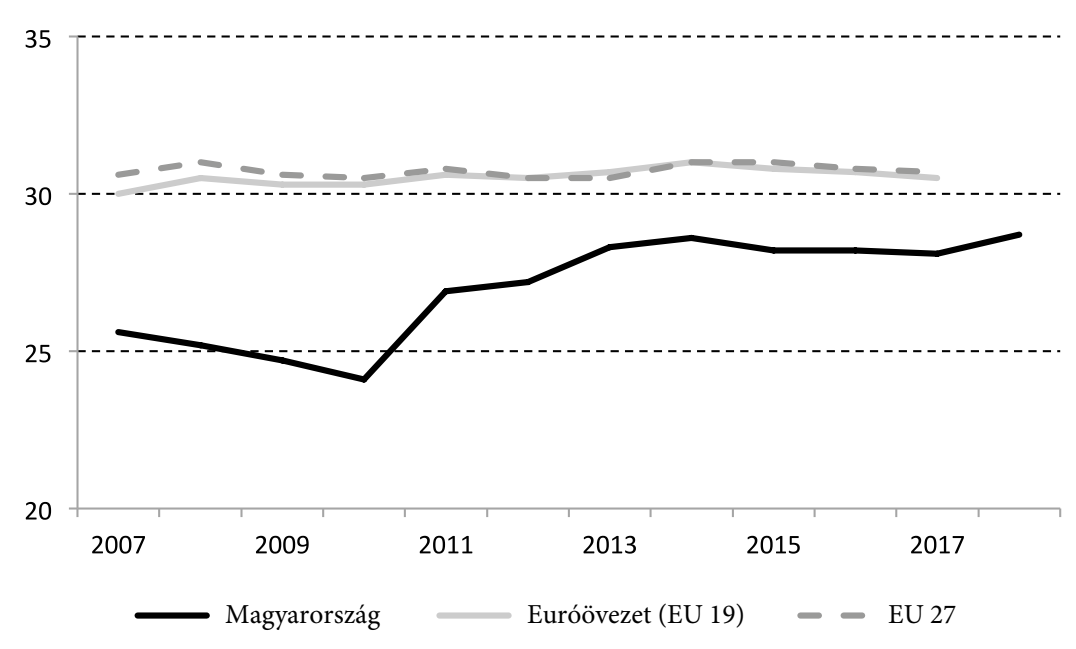

Megjegyzés: Az euróövezetre és az EU-ra vonatkozó legfrissebb adatok 2017-re vonatkoznak. Forrás: Eurostat

A 2. ábra kiemeli, hogy a vizsgált időszakban az euróövezet és az EU Gini-koefficiense együtt haladt, és stabilnak volt tekinthetö. Ez a relatív stabilitás különösen helytálló a magyar értékek figyelembevételével. Magyarországon az egyenlőtlen-

12 A o vagy o\% érték fejezi ki a tökéletes egyenlőséget (mindenki azonos vagyonnal vagy jövedelemmel rendelkezik a társadalomban), míg az 1 vagy 100 százalék a maximális egyenlőtlenséget tükrözi (egy személynél koncentrálódik az összes vagyon vagy jövedelem). 
ség mértéke alacsonyabb az euróövezet vagy az EU átlagához viszonyítva. A válság idején a magyar társadalmi egyenlőtlenség egyértelműen visszaesett, majd a folyamat 2010-ben fordulatot vett, és a Gini-koefficiens ismét növekedni kezdett. Ez a folyamat lassú konvergálást mutat az EU-s átlag irányába. Amennyiben ez a „felzárkózás” folytatódik, akkor a leggazdagabb társadalmi csoportban növekvő vagyonkoncentrációra számíthatunk. Utóbbi állítást különböző tanulmányok és statisztikák támasztják alá, amelyek arra világítanak rá, hogy a növekvő egyenlőtlenség nemcsak a legszegényebbek szegényebbé válásának a következménye, hanem annak az eredménye is, hogy a leggazdagabbak még gazdagabbá válnak (lásd 5. ábra). ${ }^{13}$

A 3. ábra összehasonlítja a magyar és az EU reál-GDP növekedési rátáit, valamint a háztartások pénzügyi vagyonát a nominális GDP százalékában kifejezve. Az előbbi a valós konvergenciafolyamatról, míg az utóbbi a pénzügyi eszközök GDPhez viszonyított arányáról nyújt információt. Ez a százalékos arány a magyar és az EU-s esetben nagy eltérést mutat. Ebből az aspektusból nézve: amennyiben létezik ok a konvergenciavárakozásra, akkor ebben az esetben a pénzügyi eszközök növekedési potenciálja jelentős. Ennek ellenére a magyar és az EU-s idősorok az elmúlt években nem konvergáltak. Másrészről a mutatók mindkét esetben felfelé irányuló tendenciát mutatnak, ami azt jelenti, hogy a háztartások pénzügyi vagyonának növekedése felülmúlta a reál-GDP növekedését. Ezek a tendenciák az egész pénzügyi szektor számára növekedési lehetőséget kínálhatnak.

13 Az állítás alátámasztására, valamint a szocialista korszak magyarországi társadalmi egyenlőtlenségéről és annak mozgatórugóiról lásd például MAVRidis-MosBERGER (2017), TóTHSZELÉNYI (2018) vagy MNB (2019). A növekvő egyenlőtlenségeket természetesen globális szinten is vizsgálják, igaz, a háttérfolyamatok országonként vagy régiónként eltérőek. Áttekintéshez és politikai következtetésekhez lásd STIGLITz (2012). Megemlíthető, hogy a privát banki piaci növekedést alátámasztja Milanovic úgynevezett „elefántábrája” (Milanovic, 2012). 


\section{3. ábra}

\section{A háztartások teljes pénzügyi vagyona ${ }^{\star}$ és a reál-GDP növekedési üteme ${ }^{\star \star}$}

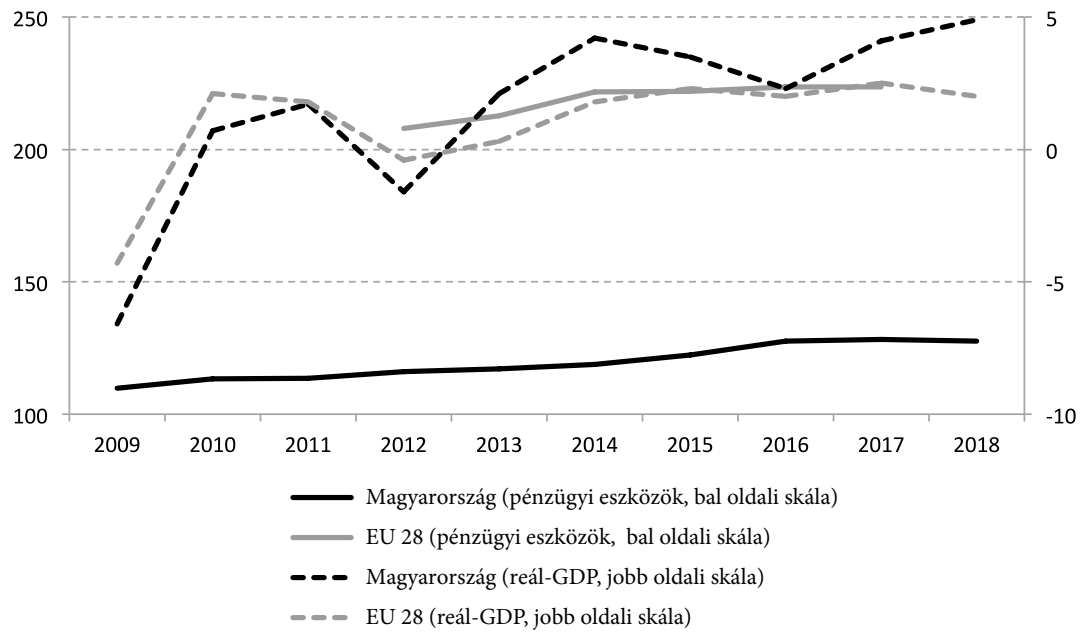

Megjegyzés: * a GDP százalékában kifejezve, bal oldali skála; ${ }^{* *}$ százalékos változás az előző évhez képest, jobb oldali skála.

Jelenleg az „EU 28” esetében a háztartások pénzügyi eszközeire vonatkozó statisztikák a 2012 és 2017 közötti időszakra érhetők el.

Forrás: Eurostat

Magyarországra fókuszálva, a 4. ábra három releváns mutatót vetít ki, amelyeket áttekintve, az alábbi következtetéseket lehet levonni: először is érdemes kiemelni a pénzügyi vagyonállomány volatilitását. Ez a gazdaság teljesítményének ciklikusságával, valamint az eszközosztályok újraértékelődésével magyarázható. A PB-piac által kezelt vagyonállomány esetében nagyobb volatilitás figyelhető meg, mint az összes háztartás pénzügyi vagyonában. További kulcsfontosságú tény, hogy a pénzügyi vagyon növekedésének üteme általában meghaladja a releváns makrogazdasági mutatók növekedését, nevezetesen a reál- és a nominális GDP növekedését. A 4. ábra az utóbbi mutatót használja, mivel a pénzügyi vagyon értékelése szempontjából ez relevánsabb; míg a reál-GDP-t a 3. ábra szemlélteti. Végül, de nem utolsósorban, a háztartások teljes pénzügyi vagyonállományának esetében is jól megfigyelhető a gyarapodás. 


\section{4. ábra}

\section{Releváns növekedési mutatók}

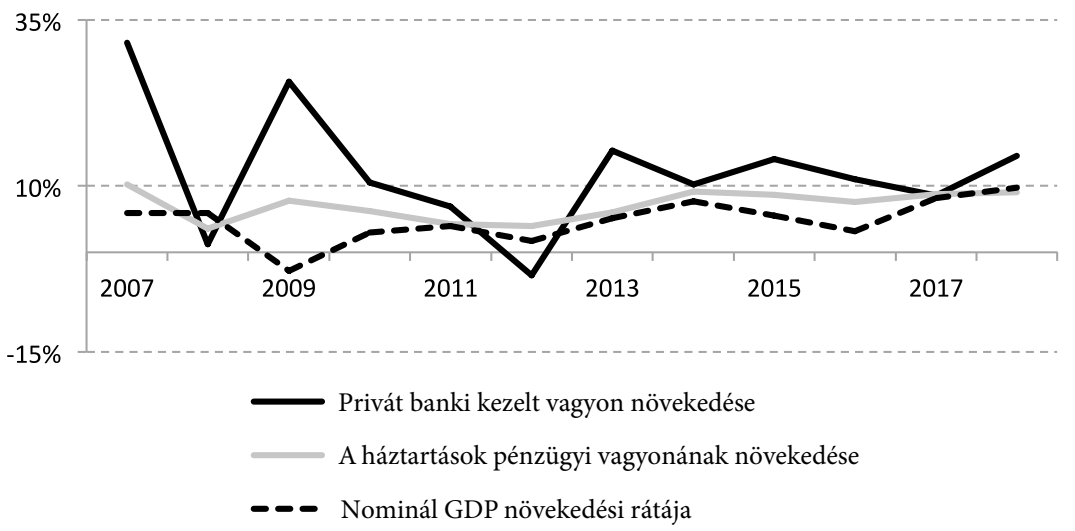

Megjegyzés: A növekedési ráták a felsorolt forrásokon alapuló saját számítások.

Forrás: KSH-statisztikák; MNB-statisztikák; Portfolio.hu: Privát bankok; saját számítások.

Mindkét kifejezésre kitértünk már, fontos azonban tisztázni a legrelevánsabb különbségeket a jövedelem és a pénzügyi vagyon között. Többek közt azért fontos ez, mert a privát bankok szegmentációs korlátjuk meghatározásához az utóbbit használják. Kezdjük a pénzügyi vagyon szempontjából a csoport egy karakterisztikus jellemzőjével: a legfelső decilisbe tartozó háztartások általában egy vagy több cégben is rendelkeznek részesedéssel (MNB, 2017). Így a vállalati befektetésekkel összefüggésben általában a vagyon számos év alatt halmozódik fel. Ezzel szemben a jövedelem alapján a legmagasabb decilisbe tartozó háztartások jövedelmét kevésbé határozza meg a vállalati tulajdonjog. Továbbá, ezek a háztartások az elit klubban sok esetben „újoncok”, és „csak” valószínűsíthetően válnak jövőbeli potenciális $\mathrm{PB}$-ügyfelekké. Ezáltal nem teljesen azonos a két csoport összetétele. Mindezek ellenére a pénzügyi vagyon és jövedelem szempontjából a legfelső 10 százalékhoz tartozók rendelkeznek a társadalom legnagyobb pénzügyieszközhányadával. Kiemelhetö, hogy a legfelső decilisben a pénzügyi vagyon koncentráltabb, mint a jövedelem tekintetében, azaz nagyobb mértékü az egyenlőtlenség a pénzügyi vagyon tekintetében. ${ }^{14}$

14 A vonatkozó adatokhoz lásd MNB (2017:48-49). Az MNB tanulmányában a korszerkezetre és a regionális különbségekre vonatkozó statisztikai adatok találhatók. Az előbbi megalapozza mind az öröklési tervezés, mind pedig a fiatalabb generációra való összpontosítás fontosságát. A regionális mutatók pedig rávilágítanak a vagyonkoncentrációra Budapesten és környékén. Továbbá figyelemre méltó az a tény is, amely szerint szinte minden (potenciális) PB-ügyfél már a pénzügyi szek- 
Az 5. ábra a jövedelmet és a pénzügyi vagyont mutatja be decilisenként. Néhány következtetést érdemes megjegyezni. Elsősorban: tisztán látható a jövedelmet és a pénzügyi vagyont ábrázoló görbék összehasonlításánál, hogy a vizsgált időszakban az utóbbi koncentrációja a felső decilisekben jelentősen nagyobb mértékű. Másodszor, a jövedelmi szintek görbéi ugyan kevésbé meredekek, a felsőbb decilisekben azonban fokozatos növekedés figyelhető meg, ami jó hír a „prémium” banki és privát banki szolgáltatók számára. Fontos azt is látni, hogy 2010 és 2017 között nagyobb jövedelmek koncentrálódtak a magasabb decilisekben. A görbék az évek során „szétnyíltak”, és egyre meredekebbé váltak. Ezen tények is a lassan növekedő egyenlőtlenség állítását támasztják alá. Összességében, nyomon követve az 5. ábra számait, egyre jobban kirajzolódnak a társadalmi egyenlőtlenségre és a pénzügyi eszközök koncentrációjára utaló jelek.

\section{5. ábra}

A jövedelem és a teljes pénzügyi eszközök adatai decilisenként (forintban)

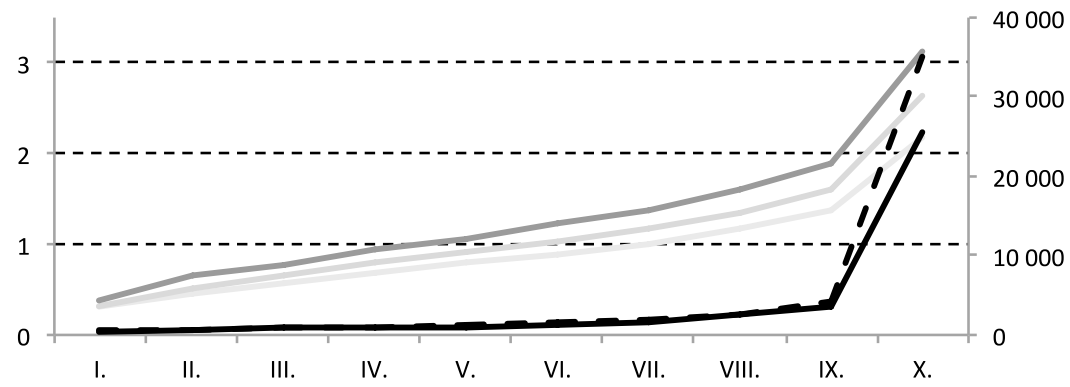

Jövedelem (2010, millió, bal oldali skála)

Jövedelem (2014, millió, bal oldali skála)

— Jövedelem (2017, millió, bal oldali skála)

— Pénzügyi eszközök (2014, milliárd, jobb oldali skála)

- - Pénzügyi eszközök (2017, milliárd, jobb oldali skála)

\footnotetext{
Megjegyzés: A jövedelemre vonatkozó adatok az éves egy före jutó nettó jövedelemre vonatkoznak. A pénzügyi eszközökre vonatkozó statisztikáknál a deciliseket 2014-ben a teljes vagyon, míg 2017-ben a nettó vagyon alapján képezték.

Forrás: KSH-statisztikák; MNB (2017:68); MNB (2019:7).

tor ügyfele, ebből elmondható, hogy a PB-piac pénzügyi integrációja szinte teljes. Az eszközök összetételét illetően a diverzifikált pénzügyi megtakarítási struktúra tipikusan a felső szegmensre jellemző. Az is észrevehető, hogy a társadalomban a pénzügyi eszközök sokkal koncentráltabbak, mint a reáleszközök. A tények a vagyonkezelési szolgáltatások szükségességét támasztják alá, míg a privát bankárok az ügyfelek „oktatási” folyamatában játszanak kulcsszerepet. (Az utóbbihoz kapcsolódóan HUNG et al. (2009) a pénzügyi ismeretek fontosságáról nyújt áttekintést.)
} 
Összefoglalva, a nagyobb vagyonkoncentráció a felső decilisben azt jelenti, hogy egy nagyobb társadalmi csoport éri el az adott PB-s szegmentációs határokat, ezzel növelve a potenciális privát banki ügyfélszámot. Másik szempontból megközelítve, a legfelső kategóriába tartozó 400 ooo háztartás esetében nagy mennyiségü pénzügyi vagyon koncentrálódott az évek során, ami a kezelt vagyon oldaláról is támogatja a PB-s növekedési lehetőségeket. Párhuzamosan a pénzügyi vagyon felhalmozódásával, a jövedelem koncentrációja is fennáll. A két csoportot illetően - a pénzügyi vagyon és a jövedelem által képzett legfelső decilisekben - természetesen jelentős átfedés van, azonban vannak olyan „újoncok”, akik a privát bankok jövőbeni célközönségét testesítik meg. Megállapítható, hogy ha az ismertetett tendenciák folytatódnak, a potenciális PB-ügyfélkör mérete tovább növekedhet mind az ügyfélszám, mind a pénzügyi vagyon tekintetében.

\section{MEKKORA A „TÉR” A PRIVÁT BANKI SZEKTOR SZÁMÁRA?}

\subsection{Módszertani nehézségek}

Az országok többségében érdekes és releváns kérdés, hogyan lehet megbecsülni a privát banki szektor potenciális ügyfélszámát és a pénzügyi vagyonát. De miért is nehéz a privát banki szektor célcsoportját megbecsülni? Lássunk néhány releváns tényezőt!

- Magyarországon - akárcsak az országok nagy részében - nem állnak rendelkezésre hivatalos statisztikai adatok a legfelső decilis és percentilis pénzügyi vagyonáról.

- Westermeier-Grabka (2015) több statisztikai torzító tényezőt sorol fel, miközben megkísérlik megbecsülni a leggazdagabb egyének számát és vagyonát. Például a fizetések esetében figyelembe kell venni azt a tényt, hogy a leggazdagabb egyének pénzügyi vagyona jóval egyenlőtlenebbül oszlik meg, mint a fizetések. Jelen tanulmányunk már rávilágított, hogy ez nemcsak nemzetközi szinten, hanem Magyarországon is érvényes. Mindezek tükrében az adóalapú statisztikák nem vezetnek helyes eredményhez a potenciális privát banki mozgástér becslése során.

- Folytatva az adóalapú statisztikákkal, vitathatóságuk két alapvető okra vezethető vissza. Az egyik az, hogy ezek az adatok egy adminisztratív folyamat részei, és nem az igényekhez igazodnak. Másodszor, különösen a nagyobb vagyonnal rendelkező emberek éreznek egyfajta ösztönzést arra, hogy adóköteles jövedelmüket alulértékeljék (Atkinson-Piketty, 2010). Mindezek mellett figyelembe kell venni a szürke- vagy feketegazdaság méretét is, amely torzít minden hivatalos statisztikát. Még a World Bank (2016) jelentése is hangsú- 
lyozza, hogy a legnagyobb jövedelemmel rendelkező háztartások jövedelmeit jellemzően „alulripoltálják”.

- Az ország elhagyása az adófizetés elkerülésének egy extrém példája (Atkinson-Piketty, 2010). Pontosan nem lehet megbecsülni azon pénzügyi eszközök összegét, amelyeket külföldön tartanak, például úgynevezett „offshore paradicsomokban”. A „kimenekített” pénzügyi eszközök megbecsüléséhez kiindulópontként szolgálhat a nem nyomon követett tőkeáramlás - a tévedések és kihagyások egyenlege -, amely elérhető adat a fizetési mérlegekben (Atkinson-Piketty, 2010). Ugyanakkor ez pusztán becslésekhez vezethet. Nyilvánvaló, hogy Magyarországon is létezik egy célcsoport, amely megtakarításainak legalább egy részét külföldön kívánja tartani. ${ }^{15}$

- A privát banki statisztikák segíthetik a releváns tendenciák elemzését. Magyarországon a jelenlegi privát banki szektorról rendelkezésre állnak statisztikai adatok - nevezetesen a szolgáltatók ügyfélszámai és a kezelt pénzügyi vagyon. Azonban ezeknek az adatoknak az összehasonlítása több okból is problémás lehet. Először is a privát bankok különböző szegmentációs határokat alkalmaznak, és alkalmanként még módosítják is őket. Másodszor, a számokat torzíthatják az esetleges egyesülések és felvásárlások. Harmadszor, közismert, hogy a jelentett számok jelentős részénél az ügyfelek a szegmentációs limitnél alacsonyabb megtakarítással rendelkeznek, ugyanakkor mégis élvezhetik a privát bankok által nyújtott szolgáltatásokat. Mindezek mellett számos ügyfél két vagy több pénzügyi intézmény között diverzifikálja megtakarításait, ezáltal torzítva az ügyfélszámlák számára vonatkozó adatokat.

- Általános probléma, hogy a potenciális privát banki ügyfelek különböző instrumentumokban tartják vagyonukat, és rendszeresen módosítják portfóliójukat. Számos olyan nagy vagyonnal rendelkező ember van, aki vagyonának jó részét reáleszközökben tartja. Például értékes családi vállalkozásokkal vagy ingatlantulajdonokkal rendelkezik. Vajon ezen kör potenciális privát banki ügyfélnek tekinthető? Miképpen kell értékelni azon ügyfeleket, akik pénzügyi megtakarításaikból ingatlanokat vásárolnak? A rendelkezésre álló statisztikai adatok alapján Magyarországon az elmúlt néhány évben az ingatlanbefektetésekbe jelentős vagyon áramlott, felfelé mutató tendencia mellett. ${ }^{16}$ Ami a PB-t illeti, gyakori, hogy azon ügyfelek, akik reáleszközöket vásárolnak, nem ma-

15 Magyarországon átmenetileg bevezettek egy speciális, kedvezményes adófeltételeket kínáló bankszámlát, amelynek célja a külföldön tartott megtakarítások hazacsatornázása volt. 2014 és 2016 között mindössze 2141 ügyfél 155,6 milliárd forintot utalt vissza Magyarországra (Portfolio. hu: Privát bankok).

$16 \mathrm{Az}$ ingatlanpiaci áttekintéshez lásd KSH (2018b). Annak érdekében, hogy betekintést kapjunk a befektetési céllal vásárolt ingatlanok arányáról, lásd a Duna House Barométerét. Figyelemre méltó 
radnak privát banki ügyfelek vagy kezelt vagyonuk lecsökken. Ennek ellenére a magas szegmenst megcélzó üzletágaknak potenciális ügyfelei maradhatnak. ${ }^{17}$ Mindezen folyamatok komplex képet vázolnak.

\subsection{Alkalmazott módszertan}

A fentiekben említett nehézségek és torzító tényezők figyelembevétele miatt becsléseinket a Magyar Nemzeti Bank (MNB) adataira építjük. A felhasznált speciális adattár az Európai Központi Bank (ECB) által koordinált háztartási vagyonfelmérés (Household Finance and Consumption Survey - HFCS) részét képezi, azonban kiigazításokat is tartalmaz. ${ }^{18}$ Becsléseink a 2017-re vonatkozó nettó pénzügyi vagyon által képzett deciliseken alapulnak, ${ }^{19}$ amely feltételezésünk szerint megfelelő alapot kínál. A 2014-re vonatkozó statisztikákban a felső 1 százalék pénzügyi eszközeinek mennyisége is megtalálható (MNB, 2017:68). Ez fontos adat, hiszen támpontként szolgálhat a felső decilisen belüli vagyon eloszlására, ami egyben a privát banki szektor számára is releváns. Ugyanakkor a 2017-es pénzügyi vagyonra vonatkozó adatok csak decilisekre vonatkozó adatokat tartalmaznak, míg a felső 1 százalékról mindössze a teljes nettó vagyon tekintetében kapunk információt (MNB, 2019:11). ${ }^{20}$ Mindezeket figyelembe véve úgy határozzuk meg 2017-re az 1 százalékra vonatkozó pénzügyi eszközök értékét, hogy alapul vesszük a 2014-es adatot, majd megszorozzuk a vizsgált időszak teljes vagyonának növekedési ütemével a felső decilisben. Az egyenlőtlenség növekvő tendenciája alapján ez 2017re egy óvatos becslést eredményez a legfelső percentilis pénzügyi vagyonára.

A felső decilis pénzügyi vagyonának eloszlása vagy mediánja nem áll rendelkezésre, bár ezek nagymértékben szolgálnák céljainkat. Ezáltal, második legjobb megoldásként, a pénzügyi vagyon értékét elosztjuk a háztartások számával, ${ }^{21}$

adat, hogy 2011 és 2017 között az 50 millió forint felett vásárolt ingatlanok száma 697-röl 3118-ra, míg a 100 millió forint felett vásárolt ingatlanok száma 68-ról 359-re emelkedett (KSH, 2018a).

17 A nemzetközi szinten jellemző eszközstruktúrába betekintést kínál a Wealth-X (2018) tanulmánya. Elemzésük alapján 2017-ben a „milliárdosok” (az egymilliárd dollár feletti vagyonnal rendelkező egyének) vagyonának összetétele a következőképpen alakult: 74,8\% különböző tulajdonjogok, 22,9\% likvid eszközök (például készpénz), 2,3\% ingatlan és luxuseszközök (Wealth-X 2018:19).

18 A módszertanról további információ az MNB (2019) tanulmányában áll rendelkezésre.

19 2014-re az MNB a teljes vagyon alapján csoportosította a háztartásokat, de ez a fajta módszertani váltás nem okoz jelentős különbséget, azaz a két év eredménye összehasonlítható.

20 Ez utóbbi mutatószám reáleszközöket is magában foglal a pénzügyi eszközök mellett, így ez félrevezető mutató a privát banki potenciál becsléséhez. A releváns értékekhez lásd MNB (2019) vagy MNB (2017).

21 Az MNB (2019) által publikált statisztikákat használjuk. 
hogy megkapjuk a legfelső decilis átlagos pénzügyi vagyonát. Ez az átlag 2017-ben elérte a 88 millió forintot (lásd 2. táblázat). Ugyanebben az évben a PB piac szegmentációs határának súlyozatlan átlaga 79 millió forint volt (Portfolio.hu, 2018). A torzítás csökkentése érdekében a legalacsonyabb és a legmagasabb értékeket kivesszük, így 68 millió forint a piaci átlag. ${ }^{22}$ Az egyszerüség kedvéért ezt az utóbbi értéket fogjuk mindvégig elméleti szegmentációs határként használni. Ez a szám a valós privát banki piacon különböző szegmentálási politikákon alapszik, de itt egy fix elválasztó vonalként és mérceként kerül alkalmazásra. Ez a két szám - a 68 millió és a 88 millió forint - két különböző megközelítésre mutat rá, de jelzi, hogy hol áll az elméleti szegmentálási korlátunk a legfelső decilisek átlagához képest. Az átlagok és a szegmentációs korlátok összehasonlítása további feltételezések lehetőségét kínálja. Nevezetesen feltételezhetjük, hogy ha egy csoport átlagértéke jóval meghaladja a mércénket, akkor a csoport nagy része teljesíti az általunk támasztott kritériumokat. Ezen logika mentén az átlagértékeket fogjuk összevetni az elméletileg meghatározott szegmentálási korláttal.

Az adatok hiányossága miatt nem lehetséges egy megbízható függvényt meghatározni (lásd Függelék). Ennek ellenére, hogy rálátást kapjunk az eloszlásra, a megelőző fejezetek különböző idősorokat mutattak be az egyenlőtlenségről és a pénzügyi vagyonról. A jövedelem és a pénzügyi vagyon decilisekre bontott értékei alapján kijelenthetjük, hogy az adatok nem normál eloszlásúak, hanem meredeken emelkedő tendenciát mutatnak. Az 5. ábra éppen ezt mutatja a teljes pénzügyi vagyon mennyiségére decilisekre bontva, míg a Függelék 6. ábrája az egyes decilisek átlagos pénzügyi vagyonán keresztül mutatja ezt be.

Végezetül, mivel a pontos eloszlás nem ismert, egy tartományt határozunk meg a lehetséges privát banki ügyfélkörre. Ez mind a potenciális ügyfelek számára, mind pedig a vonatkozó pénzügyi eszközök mennyiségére utal. Konzervatív becslésként a felső 1 százalék adataira támaszkodunk, mivel a legfelső percentilis átlagos pénzügyi vagyona hétszerese az elméleti szegmentálási korlátunknak. Tehát feltételezhető, hogy az összes felső 1 százalékba tartozó háztartás 68 millió forint feletti pénzügyi vagyonnal rendelkezik. A tartomány kijelöléséhez megbecsüljük a felső 2 százalékhoz tartozó értékeket is. A vonatkozó statisztikák megadják a háztartások számát. Ahhoz pedig, hogy megbecsüljük a kapcsolódó pénzügyi eszközök mennyiségét, hozzáadjuk a felső 2-10 százalék értékének egykilencedét a

22 Ahogyan azt egy korábbi, 2018-ra vonatkozó hivatkozásban (lásd 5. lábjegyzet) bemutattuk, a súlyozott átlagot nem lehet kiszámolni az OTP Bank adatai miatt. Ismét: ha feltételezzük, hogy az OTP Bank az alacsony szegmentációs limitet (30 millió forint) alkalmazza, akkor a súlyozott piaci átlag 67 millió forint lenne, míg a másik szegmentációs limit (80 millió forint) esetében a súlyozott piaci átlag 85 millió forintra emelkedne. A kerekítés és a szerkezeti változások hiánya miatt ez a két érték megegyezik a 2018-as értékkel. 
felső percentilis pénzügyi eszközeinek összegéhez. Ez az utolsó lépés linearitást feltételez. A pénzügyi vagyon koncentrációja és az alkalmazott módszertan alapján feltételezhetjük, hogy a becsült tartomány lefedi a privát banki ügyfelek potenciális méretét.

Úgy gondoljuk, hogy a fent bemutatott módszer a legjobban szolgálja céljainkat. Ez az új megközelítés egy közelítő és egyszerüsített becslést biztosít. A fent említett egyszerüsítések következtében azonban a a pontos eredményeket óvatosan kell kezelni. Ezek pusztán becslések, amelyek maguk is az MNB (2017; 2019) által készített becsléseken alapulnak. Noha a pontos számok és az alkalmazott módszer vita tárgyát képezhetik, a jelen tanulmány elsődleges kérdése mégis határozottan megválaszolható. Továbbá abban az esetben, ha az MNB alapadatai frissítésre kerülnek, a bemutatott módszer megismételhető. Végezetül, különféle üzleti szándékok alapján az elméletileg meghatározott szegmentációs határ megváltoztatható.

\subsection{Eredmények}

Amint azt az előző módszertani alfejezetben tárgyaltuk, becslésünk és a 2. táblázat kiindulópontjai az MNB HFCS-alapú statisztikáinak a mutatószámai decilisekre bontva. A 2. táblázat utolsó sora a magyar társadalom növekvő vagyonkoncentrációját támasztja alá, ami teret nyit a privát banki tevékenység további növekedésének.

\section{2. táblázat}

\section{Csoportonkénti pénzügyi eszközök}

\begin{tabular}{|c|c|c|c|c|c|c|c|c|}
\hline & \multicolumn{4}{|c|}{2017} & \multicolumn{4}{|c|}{2014} \\
\hline & $\begin{array}{l}\text { IX. } \\
\text { decilis }\end{array}$ & $\begin{array}{c}\mathrm{X} . \\
\text { decilis }\end{array}$ & $\begin{array}{l}\text { Felső } \\
2-10 \%\end{array}$ & $\begin{array}{c}\text { Felső } \\
1 \%\end{array}$ & $\begin{array}{l}\text { IX. } \\
\text { decilis }\end{array}$ & $\begin{array}{c}\text { X. } \\
\text { decilis }\end{array}$ & $\begin{array}{c}\text { Felső } \\
2-10 \%\end{array}$ & $\begin{array}{c}\text { Felső } \\
1 \%\end{array}$ \\
\hline $\begin{array}{l}\text { Pénzügyi eszközök } \\
\text { (millió HUF) }\end{array}$ & 4334000 & 35071000 & 15533134 & 19537866 & 3680000 & 25484000 & 11287000 & 14197000 \\
\hline Háztartások száma & 400422 & 400422 & 360380 & 40042 & 412837 & 412837 & 371553 & 41284 \\
\hline $\begin{array}{l}\text { Átlagos pénzügyi } \\
\text { eszközök (pénzügyi } \\
\text { eszközök mennyisége } \\
\text { osztva a háztartások } \\
\text { számával az adott } \\
\text { csoportban, } \\
\text { millió HUF) }\end{array}$ & 10.82 & 87.59 & 43.10 & 487.93 & 8.91 & 61.73 & 30.38 & 343.89 \\
\hline $\begin{array}{l}\text { Részesedés } \\
\text { a pénzügyi eszközökből } \\
\text { (a csoport pénzügyi } \\
\text { eszközei osztva az össz } \\
\text { pénzügyi eszközök } \\
\text { mennyiségével) }\end{array}$ & $8.72 \%$ & $70.56 \%$ & $31.25 \%$ & $39.31 \%$ & $9.52 \%$ & $65.90 \%$ & $29.19 \%$ & $36.71 \%$ \\
\hline
\end{tabular}

Forrás: MNB (2017:68), MNB (2019:7-11), saját számítások 
Amint azt a 2. táblázat is illusztrálja, 2017-ben a legmagasabb decilis - 400 ezer háztartás - a teljes pénzügyi vagyon 71\%-át, vagyis 35071 milliárd forintot birtokolt. Így kiszámolhatjuk, hogy ennek a decilisnek az átlaga 88 millió forint volt, ami meghaladja a legtöbb privát bank szegmentációs határát. A fent bemutatott módszertan alapján a legfelső 1 százalék 19538 milliárd forint összegben birtokolt pénzügyi eszközöket, ami 40 ezer háztartás esetében átlagosan 488 millió forintot takar. Ez azt jelzi, hogy a felső 2-10 százalékos csoportban a 360 ezer háztartás „mindössze” 15533 milliárd forinttal rendelkezett, ami átlagosan 43 millió forintot jelent. Mindez utal a vagyonkoncentráció szintjére. A felső decilisen belüli megoszlásról további információ nem áll rendelkezésre, így további határvonalakat nem lehet meghatározni.

A felső 2 százalékba tartozó háztartások száma a felső 1 százalék duplája. Az ismertetett módszertan szerint a becsült pénzügyi eszközük értéke 21264 milliárd forint. Ezáltal a legfelső 2 százaléknak az átlagos pénzügyi vagyona 266 millió forint. Ez még mindig négyszerese az elméleti 68 millió forintos elméleti szegmentációs határnak.

\section{3. táblázat}

A privát banki piac potenciális mérete és tényleges privát banki indikátorok (2017)

\begin{tabular}{cccc}
\hline & $\begin{array}{c}\text { Becsült } \\
\text { felső 1\% }\end{array}$ & $\begin{array}{c}\text { Becsült } \\
\text { felsö 2\% }\end{array}$ & $\begin{array}{c}\text { Tényleges } \\
\text { PB-indikátorok }\end{array}$ \\
\hline $\begin{array}{c}\text { (Potenciális) kezelt vagyon } \\
\text { (millió HUF) }\end{array}$ & 19537866 & 21263770 & 4240000 \\
$\begin{array}{c}\text { Háztartások (potenciális) } \\
\text { száma }\end{array}$ & 40042 & 80084 & 41255 \\
$\begin{array}{c}\text { Átlagos pénzügyi eszközök } \\
\text { (millió HUF) }\end{array}$ & 488 & 266 & 103 \\
\hline
\end{tabular}

Megjegyzés: A második és a harmadik oszlop a fent leírt becslés eredményeit tartalmazza. A negyedik oszlopban a Portfolio.hu (2018) által publikált, 2017-re vonatkozó, tényleges PB-s indikátorok (kezelt vagyon és ügyfélszám) találhatók. Az átlagos pénzügyi eszközöket úgy számítottuk ki, hogy a pénzügyi eszközök összegét elosztottuk a háztartások számával. A tényleges PB-s indikátorok esetében az ügyfélszámlák számával osztottunk, azaz 41 255-tel.

Forrás: KSH-statisztikák; MNB (2017:68), MNB (2019:7), Portfolio.hu (2018); saját számítások

A jobb áttekinthetőség érdekében a becsült sarokköveket és a 2017. évi privát banki statisztikákat a 3. táblázat foglalja össze. A fentiekben bemutatott számítások alapján 2017-re a potenciális ügyfélszámot a 40-80 ezer közötti tartományra becsüljük. A potenciális kezelt pénzügyi vagyon esetében a tartományt 19538 milliárd forint és 21264 milliárd forint közé becsüljük. Természetesen az adott számok 
a kijelölt elméleti szegmentációs határtól és a feltételezett eloszlástól függően változtathatóak. A zárófejezetben a 3. táblázat segítségével kiemeljük a legfontosabb üzeneteket.

\section{KÖVETKEZTETÉSEK}

Jelen tanulmány a tudományos irodalomban azt az ürt tölt ki, amely a magyar privát banki üzletággal és annak növekedési lehetőségeivel kapcsolatos. Az egyenlőtlenség az elemzés egyik kulcsfontosságú témája. Magyarországon a szocialista rendszer bukását követően a társadalmi egyenlőtlenség egyértelműen növekedett, amely magával vonta a pénzügyi vagyon növekvő koncentrációját a felső 10 százaléknál. Az elmúlt tíz évben az egyenlőtlenség mértéke kisebb ingadozást mutatott, amely összefüggésben állt a gazdaság ciklikus folyamataival. 2013 óta az egyenlőtlenség mértékében bizonyos stabilitás figyelhető meg, habár továbbra is fennáll az enyhén emelkedő tendencia. Ez teret nyit további privát banki ügyfelek akvizíciójához vagy az úgynevezett „friss pénzek” becsatornázásához.

A jelenlegi magyar privát banki piac áttekintése során körvonalazódott, hogy a PB-szolgáltatók a háztartások teljes pénzügyi vagyonának már 9 százalékát akvirálták. A tanulmány rövid áttekintést nyújtott a piac sokszínűségéről. A privát banki kezelt vagyon növekedése, illetve az átlagos kezelt vagyon mértékének alakulása egyértelmü vagyonkoncentrációt tükröz. Mindezek ellenére a PB-s ügyfélszámlák számának alacsonyabb ütemü növekedése egyfajta „telítettségre” utalhat.

A tanulmány elsődleges célja az volt, hogy egy értéktartományt becsüljön meg a privát banki üzletág potenciális ügyfélszámára és a pénzügyi vagyonra. A 2017. évi adatok alapján az elméleti szegmentációs határt 68 millió forintnál jelöltük ki. A háztartások pénzügyi vagyona alapján képzett felső decilisen belül annak az eloszlásáról vagy a mediánról jelenleg azonban nem áll rendelkezésre információ. Ennek tükrében a két kijelölt változó esetében egy széles értéktartományt kellett meghatározni. Sajnos a rendelkezésre álló adatokra nem lehet megbízható függvényt felírni (lásd a Függeléket), és azt adott szegmentációs határnál „elvágni”. Mindezek következtében egy új módszertant követtünk, amely az MNB (2017; 2019) által publikált adatokra épült, valamint különböző feltételezéseket és óvatos becsléseket tartalmazott. Eredményeinkre támaszkodva a következőket állíthatjuk 2017-re vonatkozóan:

- Az elméleti szegmentációs határnál nagyobb pénzügyi megtakarítással rendelkező háztartások száma 40 ezer és 80 ezer közé esett. 
- Ugyanakkor az erőteljes vagyonkoncentráció a legfelső decilis, különösen a felső percentilis esetében arra enged következtetni, hogy a valós érték a kijelölt tartomány alsó értékéhez állt közel.

- Ami az elméleti szegmentációs határt meghaladó megtakarításokat illeti, a becsült pénzügyi vagyon 19538 milliárd forint és 21264 milliárd forint közé esett.

A bemutatott jellemzők alapján feltételezhetjük, hogy a tényleges érték az alacsonyabb számhoz állt közelebb. Amennyiben a bemutatott tendenciák folytatódnak, ezek a számok növekedni fognak, és ennek két fö oka van. Elöször is, megfigyelhető a háztartások teljes pénzügyi vagyonának a növekedése. Ezzel párhuzamosan a jövedelem és a pénzügyi vagyon által képzett felső decilisekben enyhén növekvő koncentrációt lehet megfigyelni.

Amennyiben a becsült értéktartományokat összehasonlítjuk a legfrissebb privát banki statisztikákkal - 2017-ben 41 ezer ügyfél rendelkezett 4240 milliárd forint értékű pénzügyi vagyonnal (lásd 3. táblázat) -, nyilvánvaló, hogy tágas tér nyílik a további növekedésre. A számok megdöbbentő mértékủ akvizíciós lehetőségről árulkodnak a pénzügyi vagyon tekintetében, és mérsékelt növekedési potenciálról az ügyfélszám vonatkozásában. Ez a következtetés akkor is érvényben marad, ha figyelembe vesszük, hogy bizonyos becslésekre és feltételezésekre építettük számainkat. Ez a fö üzenete a 2018. évi PB-piaci statisztikák tanulmányozásakor (lásd 2. fejezet) is fennáll.

Szemben a kezelt vagyon növekedési lehetőségével, a privát banki ügyfelek számával kapcsolatban csupán néhány ezer háztartás esetében feltételezhetünk ügyfélakvirálási lehetőséget. Ugyanakkor a célba vehető ügyfelek köre kibővül négy tényező figyelembevételével. Az első kettő a publikált PB-statisztikákhoz kapcsolódik, míg az utolsó kettő az alkalmazott módszertanunkból származik. Elöször is a jelenlegi PB-statisztikák nem tükrözik, hogy az egyes ügyfelek egynél több banknál vezetnek-e számlát. Másodszor pedig nem mutatják meg, hogy egyes ügyfelek pénzügyi megtakarítása nem éri el az adott szegmentációs határt, így a valószínűsíthető, „valódi” PB-ügyfélszám alacsonyabb. Harmadszor, a háztartási statisztikák és a módszertanunk nem vette figyelembe, hogy egy háztartáson belül egynél több személynek is lehet PB-számlája.. ${ }^{23}$ Végezetül, a potenciális ügyfélkör az elméleti szegmentációs határ csökkentésével is bővíthető. A négy faktor együttesen növeli az akvirálható ügyfélszámot.

23 A bankszámlák számával összefüggésben ki kell hangsúlyozni, hogy a felső decilis 52\%-a legalább kéttagú háztartásban él (MNB, 2019:5). Másképpen megközelítve, 2017-ben a legfelső decilis háztartásai átlagosan 1,8 taggal rendelkeztek (KSH-statisztikák). Ezekből következik, hogy amikor a potenciális privát banki ügyfélszámlák számát becsüljük, a háztartások számánál magasabb értéket kell kapnunk. Ugyanakkor ebben a tanulmányban ezen különbség becslését nem végezzük el. 
Különböző okokra lehet visszavezetni a nem akvirált ügyfelek számát vagy a nem akvirált megtakarítások mértékét. Az egyik, hogy a felső szegmensre vonatkozó, elérhető statisztikák megbízhatatlanok. További tényező lehet még a magyar gazdaságban használt magas készpénzarány. ${ }^{24} \mathrm{~A}$ készpénz nyomon követése nehézkes, illetve a készpénz akár a szürke- vagy a feketegazdasághoz is kapcsolódhat. Ezenkívül valószínűsíthető, hogy jelentős pénzügyi eszközöket tartanak „offshore-paradicsomokban”. A lehetséges okokkal folytatva, sok háztartás ragaszkodik az általa megszokott retail- vagy affluens üzletágakhoz, így nehezen csatornázhatók át a privát banki szolgáltatásokhoz. Olyan esetekkel is találkozhatunk, amikor vagyonos ügyfelek más pénzügyi intézményeket választanak, például nem PB-biztosítótársaságokat. A lista folytatható, de a vizsgálathoz kapcsolódó, említett nehézségek miatt csupán feltételezéseket és lehetséges okokat fogalmazhatunk meg.

Összességében azt a következtetést vonhatjuk le, hogy feltételezhetően van még lehetőség a privát banki ügyfélszám növelésére, és vitathatatlanul jelentős tér nyílik a PB-s kezelt vagyon állományának növelésére. A tanulmány módszertanát és becsült értékeit lehet vitatni. Ugyanakkor az elsődleges feladat az volt, hogy megvizsgáljuk, van-e további növekedési potenciál a privát banki üzletág számára, illetve átfogó képet kívántunk adni a jelenlegi privát banki piacról. A tanulmány fö üzenete várhatóan nem változik, hacsak nem történik valami radikális átrendeződés a pénzügyi piacon. Továbbá, a pénzügyi vagyonkoncentráció és az egyenlőtlenség áttekintett tendenciái alapján, a privát banki növekedési lehetőségek bővülésére számíthatunk az elkövetkező években.

(Az adatgyüjtés lezárása: 2019. o8. o1.)

24 2018-ban a háztartások 4792 milliárd forintot készpénzben (ami 2015 év végétől 33\%-os növekedést tükrözött) és 9006 milliárd forintot betétben tartottak, míg hivatalosan 731 milliárd forintot külföldön helyeztek el (MNB-statisztikák). 2005 óta a készpénz mennyisége a GDP arányában emelkedő tendenciát mutat, így az arány 2016-ra elérte a 13\%-ot (BELHÁZYNÉ ILLÉs-LeszKó, 2017:3). A tendencia mögött lévő okokról lásd BELHÁZYNÉ ILLÉs-LEszKó (2017). Ezek a számok a teljes népességre vonatkoznak, de a nagy mennyiségű készpénzzel rendelkező, vagyonos háztartások „friss pénz” forrásainak tekinthetők a privát bankok számára. Azon vagyonos háztartások, amelyek nagy arányú betétállománnyal rendelkeznek, további diverzifikációs és vagyonkezelési szolgáltatásokat igényelhetnek. 


\section{FÜGGELÉK}

Egy statisztikai szoftver görbeillesztési eszközével megpróbáltunk egy megfelelő függvényt felírni az átlagos pénzügyi vagyonra a vonatkozó decilisek és a legfelső percentilis bontásában. A következő egyenletet kaptuk, amely két exponenciális komponenssel is rendelkezik:

$f(x)=a(\exp (b x))+c(\exp (d x))$

A koefficiensek 95\%-os konfidenciaintervallum mellett:

$a=3.9560(3.3200-4.5910)$

$b=0.9596(0.7428-1.1760)$

$c=7.959 \mathrm{e}-09(1.702 \mathrm{e}-09-1.422 \mathrm{e}-08)$

$d=17.7900(17.2300-18.3500)$

$\mathrm{Az} R$-négyzet értéke 1. A függő változó (azaz a függőleges tengely) az átlagos pénzügyi eszközöket mutatja millió forintban, míg a független változó (azaz a vízszintes tengely) a kvantiliseket reprezentálja (lásd 6. ábra).

\section{6. ábra}

Átlagos pénzügyi eszközök alakulása kvantilisenként (millió forint, 2017)

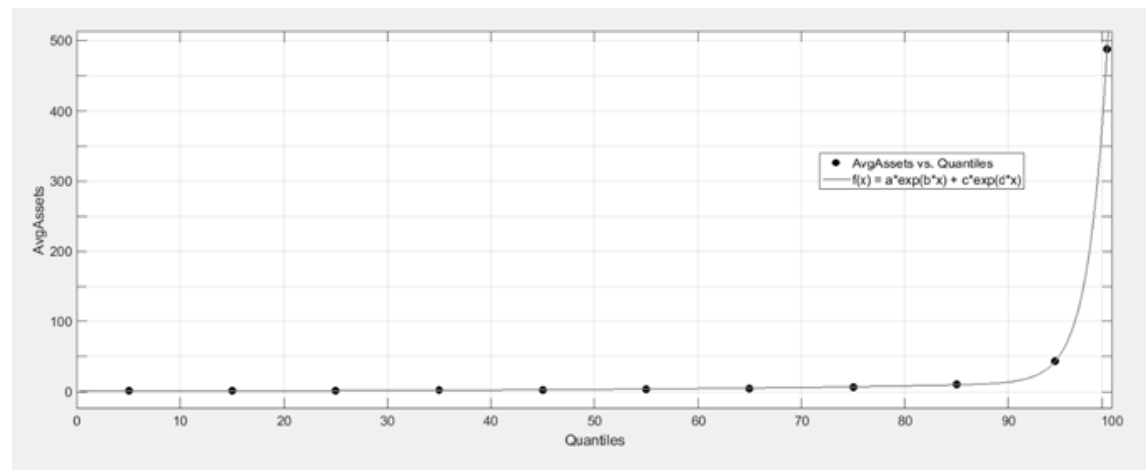

Forrás: MNB (2017:68); MNB (2019:7); saját számítások

Az ábra alapján látható, hogy a függvény bizonyos együtthatói túl szélsőséges értékeket vesznek fel, és nagymértékben fennáll a hiba lehetősége. Sajnos, az adatok hiánya miatt a felső decilisen belül pontos eloszlást nem lehet meghatározni. Ezen hiányosságok miatt nem használjuk a kapott függvényt becslésünkhöz. 


\section{HIVATKOZÁSOK}

Atrinson, A. B. - Piketty, T. (eds., 2010): Top Incomes. A Global Perspective. Oxford, New York: Oxford University Press

Belházyné Illés, ÁGNes - LeszKó, Erika (2017): Csökkenő ütemben, de továbbra is nő a készpénzállomány. Magyar Nemzeti Bank (https://www.mnb.hu/letoltes/keszpenzes-cikk-2017-03o9-veglegesmnb-honlapra.pdf, letöltve: 2018.08.15.)

Cassis, Youssef - Cottrell, Philip L. (2015): Private Banking in Europe. Rise, Retreat and Resurgence. Oxford: Oxford University Press.

Euromoney (2018): Private Banking and Wealth Management Survey 2018. Country Results. (https:// www.euromoney.com/article/b16mm70620ov22/private-banking-and-wealth-managementsurvey-2018-country-results-a-k?copyrightInfo=true, letöltve: 12.07.2018).

Filippi, Primavera De - Wright, Aaron (2018): Blockchain and the law. The rule of code. Cambridge, Massachusetts: Harvard University Press.

Hung, Angela A. - Parker, Andrew M. - Yoong, Joanne K. (2009): Defining and Measuring Financial Literacy. RAND Labor and Population, Working paper, WR-708, September 2009. (https://www.rand.org/content/dam/rand/pubs/working_papers/2009/RAND_WR708.pdf, letöltve: 2018.03.20).

Janssen, Ronald - Kramer, Bert (2015): Risk Management and Monitoring in Private Banking. Journal of Wealth Management, 18(3), 8-19.

Kochhar, Rakesh - Cilluffo, Anthony (2018): Income Inequality in the U.S. is Rising Most Rapidly Among Asians. Pew Research Center, Social \& Demographic Trends (http://www. pewsocialtrends.org/2018/o7/12/income-inequality-in-the-u-s-is-rising-most-rapidly-amongasians/, letöltve: 2018.07.15.).

KSH (2018a): 50 és 100 millió forint felett eladott lakások száma. Adatfájl a Központi Statisztikai Hivatal egyedi kérésére elkészítve (www.ksh.hu).

KSH (2018b): Statisztikai Tükör. Lakáspiaci árak, lakásárindex, 2018. I. negyedév. $26^{\text {th }}$ July 2018 (http:// www.ksh.hu/docs/hun/xftp/stattukor/lakaspiacar/lakaspiacar181.pdf, letöltve: 2018.09.01).

Huang, L. Rebecca (2017): The Psychology of High Net Worth Individuals. In: Baker, H. Kent Filbeck, Greg - Ricciardi, Victor (eds.): Financial Behavior. Players, Services, Products, and Markets. New York: Oxford University Press.

Maude, David (2006): Global Private Banking and Wealth Management. The New Realities. West Sussex: Wiley.

Mavridis, Dimitris - Mosberger, PÁlma (2017): Income Inequality and Incentives. The QuasiNatural Experiment of Hungary 1914-2008. WID.world working paper series, No. 2017/17 (https://wid.world/document/mavridis-mosberger-2017/, letöltve: 2018.08.26.).

McKinsey\&Company (2016): European Private Banking Survey 2016. Ascending against strong headwinds. McKinsey Banking Practice (https://www.mckinsey.com/ /media/McKinsey/ Industries/Financial\%2oServices/Our\%2oInsights/European\%2oPrivate\%2oBanking\%2O Survey\%202016\%20Ascending\%2oagainst\%20strong\%2oheadwinds/European-privatebanking-survey-2016.ashx, letöltve: 2018.07.12.).

Milanovic, Branko (2012): Global Income Inequality by the Numbers: in History and Now. An Overview. Policy Research Working Paper 6259, The World Bank, Development Research Group, Poverty and Inequality Team (http://documents.worldbank.org/curated/ en/959251468176687085/pdf/wps6259.pdf, letöltve: 2018/07/o9).

MNB (2017): A háztartások pénzügyi megtakarításai mikro- és makrostatisztikai adatok alapján. Magyar Nemzeti Bank (https://www.mnb.hu/letoltes/ha-ztarta-sok-eng.PDF, letöltve: 2019.06.24). 
MNB (2019): Miből élünk? A 2017-es háztartási vagyonfelmérés első eredményeinek bemutatása. Magyar Nemzeti Bank (https://www.mnb.hu/letoltes/vagyonfelmeres-2017-web-en.pdf, letöltve: 2019.06.19.).

Portfolio.hu (2007): Feltárul a leggazdagabbak világa! - minden a privát banki szolgáltatásokról. (https://www.portfolio.hu/users/elofizetes_info.php?t=cikk\&i=79062, letöltve: 2018.08.17.).

Portfolio.hu (2018): Átlépte a magyar milliomosklub a bűvös határt - Sosem voltak még ilyen gazdagok. (https://www.portfolio.hu/users/elofizetes_info.php?t=cikk\&i=276777, letöltve: 2018.08.17.).

Portfolio.hu (2019): Jön a következő válság? Biztonságosabb befektetést keresnek a magyar gazdagok. (https://www.portfolio.hu/finanszirozas/privat-bank/jon-a-kovetkezo-valsag-biztonsagosabbbefektetest-keresnek-a-magyar-gazdagok.311779.html, letöltve: 2019.06.13).

Stiglitz, Joseph E. (2012): The price of inequality. London: Penguin Books.

TóTH, IsTVÁN GYÖRGY - SzelÉNYI, IVÁN (2018): Bezáródás és fluiditás a magyar társadalom szerkezetében. Adatolt esszé a felső középosztály bezáródásáról. In: Kolosi, TAMÁs - TóTH, IsTváN GYÖRGY (szerk.): Társadalmi riport 2018. Budapest: TÁRKI.

Wealth-X (2018): Billionaire Census 2018. (https://www.wealthx.com/wp-content/uploads/2018/05/ Wealth-X_Billionaire_Census_2018.pdf, letöltve: 11.07. 2018).

Westermeier, Christian - Grabka, Markus M. (2015): Significant Statistical Uncertainty over Share of High Net Worth Households. DIW Economic Bulletin. Volume 5, Issue 14/15, 210-219. (https://www.diw.de/documents/publikationen/73/diw_01.c.500041.de/diw_econ_bull_2015-14. pdf, letöltve: 2018.07.12.).

World Bank (2016): Poverty and shared prosperity 2016. Taking on inequality. Washington DC, International Bank for Reconstruction and Development / The World Bank (https://openknowledge. worldbank.org/bitstream/handle/10986/25078/9781464809583.pdf, letöltve: 2018.07.08.).

World Bank (2018): The Global Findex Database 2017. Washington DC, International Bank for Reconstruction and Development / The World Bank (https://globalfindex.worldbank.org/, letöltve: 2018.07.17.).

\section{Internetes oldalak}

Duna House: Barométer (https://dh.hu/barometer).

ECB (European Central Bank): Household Finance and Consumption Survey (HFCS) (https://www. ecb.europa.eu/stats/ecb_surveys/hfcs/html/index.en.html).

Eurostat (http://ec.europa.eu/eurostat).

KSH (Központi Statisztikai Hivatal): Statisztikák (http://www.ksh.hu/engstadat).

MNB (Magyar Nemzeti Bank): Statisztikák (http://www.mnb.hu/statisztika/statisztikai-adatokinformaciok/adatok-idosorok/xii-a-nemzetgazdasag-penzugyi-szamlai-penzugyi-eszkozokes-kotelezettsegek-allomanyai-es-tranzakcioi/teljes-koru-minden-szektorra-vonatkozopenzugyi-szamlak/idosoros-tablak-szektoronkent-scv-k-nelkul).

Portfolio.hu: Privát bankok (https://www.portfolio.hu/cimke/Priv\%C3\%Ar\%2obank).

VIX index (http://www.cboe.com/products/vix-index-volatility/vix-options-and-futures/vix-index/ vix-historical-data). 